Мельник Л. В., к.е.н., доцент (Національний університет водного господарства та природокористування, м. Рівне)

\title{
АНАЛІЗ ЗАКОНОДАВЧОЇ БАЗИ ЩОДО ІПОТЕЧНОГО КРЕДИТУВАННЯ СІЛЬСЬКОГОСПОДАРСЬКИХ ВИРОБНИКІВ
}

В статті проведено аналіз діючої законодавчої бази з питань іпотечного кредитування сільськогосподарських виробників. Наведено порівняльну характеристику законодавчих актів, що визначають правові засади функціонування іпотечного кредитування. Систематизовано види іпотечних цінних паперів. Обгрунтовано потребу в подальшій оптимізації нормативно-правової бази з метою покращення умов доступу до позикових фінансових ресурсів суб'єктів малого та середнього агробізнесу.

Ключові слова : державне регулювання іпотечного кредитування, механізм державного регулювання, земельно-іпотечне кредитування, аграрне виробництво.

Забезпечення сприятливих умов для існування аграрного бізнесу та підтримання його конкурентоспроможності на належному рівні неможливе без участі держави як суб'єкта регулювання та учасника економічних відносин. Необхідність державної підтримки у сфері забезпечення інвестиційної привабливості аграрної галузі через іпотечний механізм зумовлено історичним досвідом та не втрачає своєї актуальності у сучасних умовах економічного розвитку.

Дослідженню механізму державного регулювання іпотечного кредитування присвячено праці таких вчених, як В. Борисова, 0. Євтух, В. Лагутін, С. Крукчок, М. Калінчик, П. Макаренко, М. Малік, М. Савлук, П. Саблук, М. Федоров та багатьох інших. Разом з тим потребують подальшого вивчення основні фактори провадження державної політики у сфері іпотечного кредитування, основним серед яких $\epsilon$ наявність відповідного законодавства, спрямованого на створення сприятливого інвестиційного клімату сільськогосподарського виробництва України.

Метою даної роботи $€$ дослідження існуючої законодавчої бази з державного регулювання й підтримки іпотечного кредитування та виокремлення напрямків її удосконалення.

3 початку незалежності нашої держави і до сьогодення в Україні було прийнято та скасовано значну кількість законодавчих актів, які тим чи іншим чином здійснювали спроби врегулювати іпотечні 
відносини, зокрема і в аграрній сфері. Нестабільність законодавства $€$ індикатором трансформаційної економіки, коли перехід від командно-адміністративної до ринкової системи відбувається на тлі змін у політичній системі, наростаючої соціальної напруженості та необхідності часткового відновлення, а, подекуди, і повної відбудови обірваних зовнішньоекономічних зв'язків держави.

На даний час правові засади функціонування іпотечного кредитування в Україні визначено Конституцією України, Законом України «Про іпотеку», Законом України «Про заставу», Земельним кодексом України, Законом України «Про іпотечне кредитування, операції 3 консолідованим іпотечним боргом та іпотечні сертифікати», Законом України «Про оцінку земель», Господарським кодексом України, Законом України «Про державну реєстрацію речових прав на нерухоме майно та їх обмежень», Законом України «Про оцінку майна, майнових прав та професійну оціночну діяльність в Україні», Цивільним кодексом України, Законом України «Про охорону земель», Законом України «Про цінні папери і фондовий ринок» тощо.

Як зазначає Ю. Л. Мохова, Закон України «Про іпотеку» вважається одним із найпрогресивніших у Центральній та Східній Європі, оскільки зорієнтований на захист інтересів кредиторів і системно регулює іпотечні відносини [1, С. 88].

Відповідно до Закону України «Про іпотеку» іпотекою визначається вид забезпечення виконання зобов'язання нерухомим майном, що залишається у володінні і користуванні іпотекодавця, згідно 3 яким іпотекодержатель має право в разі невиконання боржником забезпеченого іпотекою зобов'язання одержати задоволення своїх вимог за рахунок предмета іпотеки переважно перед іншими кредиторами цього боржника у порядку, встановленому Законом [2].

Поняття нерухомого майна (нерухомість) включає в себе земельні ділянки, а також об'єкти, розташовані на земельній ділянці і невід'ємно пов'язані з нею, переміщення яких $€$ неможливим без їх знецінення та зміни їх призначення. Іпотека виникає на підставі договору, закону або рішення суду. До іпотеки, яка виникає на підставі закону або рішення суду, застосовуються правила щодо іпотеки, яка виникає на підставі договору, якщо інше не встановлено законом. Взаємні права і обов'язки іпотекодавця та іпотекодержателя за іпотечним договором виникають з моменту його нотаріального посвідчення. У разі іпотеки, яка виникає на підставі закону або рішення суду, взаємні права і обов'язки іпотекодавця та іпотекодержателя виникають з дня вчинення відповідного правочину, на підставі якого виникає іпотека, або з дня набрання законної сили рішенням суду 
[3].

При цьому варто зауважити, що згідно із Законом усі обмеження щодо відчуження і цільового використання земельних ділянок, встановлені Земельним кодексом України, продовжують діяти і при їх іпотеці

Крім вищезгаданого Закону, належну правову базу державного регулювання і підтримки використання ресурсного потенціалу іпотечного кредитування в аграрній сфері створюють:

1. Закон України «Про іпотечне кредитування, операції з консолідованим іпотечним боргом та іпотечні сертифікати», що встановлює відносини у системі іпотечного кредитування, а також перетворення платежів за іпотечними активами у виплати за іпотечними сертифікатами із застосуванням механізмів управління майном [4].

2. Закон України «Про іпотечні облігації», що визначає правові засади емісії та обігу іпотечних облігацій, вимоги до їх іпотечного покриття, а також особливості державного регулювання і нагляду у цій сфері [5].

3. Закон України «Про оцінку земель», що визначає правові засади проведення оцінки земель, професійної оціночної діяльності в Україні з метою захисту законних інтересів держави та інших суб'єктів правовідносин у питаннях оцінки земель, інформаційного забезпечення оподаткування та ринку земель, а також розмежовує питання нормативної та експертної грошової оцінки земельних ділянок [6].

4. Закон України «Про державну реєстрацію речових прав на нерухоме майно та їх обтяжень», що регулює відносини, які виникають у сфері державної реєстрації речових прав на нерухоме майно та їх обтяжень, і спрямований на забезпечення визнання та захисту державою таких прав [7].

Детальніша характеристика комплексу нормативно-правових актів, що регулюють іпотечні відносини в аграрній сфері, діючих на даний час в Україні представлено у таблиці.

Проведений нами аналіз вітчизняної законодавчої бази стосовно кредитування під заставу нерухомості, в тому числі земельних ділянок сільськогосподарського призначення, дає можливість зробити висновки про наявність достатньо чіткого порядку кредитування фізичних та юридичних осіб під заставу нерухомого майна та майнових прав. Зокрема, в Законах України «Про іпотеку» та «Про заставу» [2; 8] визначені види нерухомого майна та майнових прав, які можуть виступати предметом іпотечного кредитування, а також умови настання іпотечних відносин та порядок укладання відповідних договорів. У ст. 8 Закону України «Про іпотеку», ст. 10 Закону України «Про заставу», ст. 352-355 Господарського кодексу України визна- 
чено вимоги щодо обов'язкового та добровільного страхування нерухомого майна, що виступає в якості застави.

Таблиця

Порівняльна характеристика законодавчих актів України щодо іпотечного кредитування аграрного виробництва

\begin{tabular}{|c|c|c|c|c|c|c|c|c|c|}
\hline 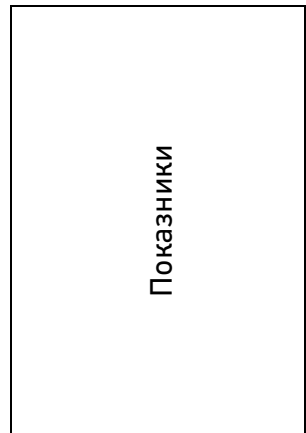 & 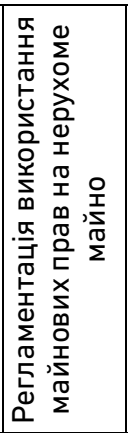 & 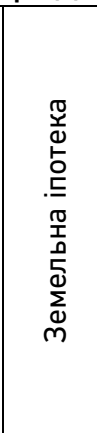 & 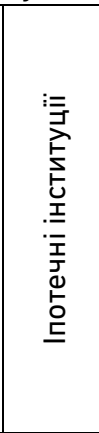 & 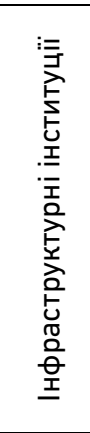 & 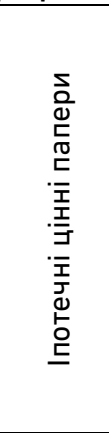 & 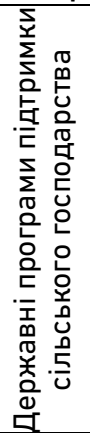 & 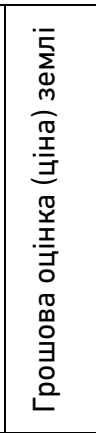 & 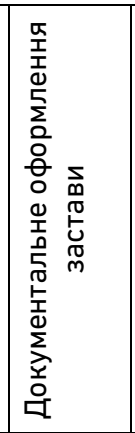 & 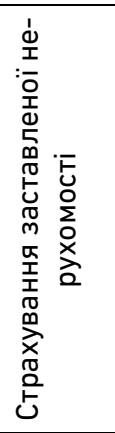 \\
\hline $\begin{array}{l}3 У \text { «Про іпотеку» } \\
(2003)\end{array}$ & & $\begin{array}{l}\text { CT. } \\
15\end{array}$ & $\begin{array}{l}\text { ст. 28, } \\
31,32\end{array}$ & & $\begin{array}{l}\text { ст. 20, } \\
30-32\end{array}$ & & & розділ 2 & ст. 8 \\
\hline $\begin{array}{l}\text { 3У «Про заставу» } \\
(1992)\end{array}$ & $\begin{array}{c}\text { ст. } 4,23, \\
27, \text { роз- } \\
\text { діл } 5\end{array}$ & ст. 4 & & $\begin{array}{l}\text { ст. } 5 \text {, } \\
53\end{array}$ & & & $\begin{array}{c}\text { СТ. } 12 \\
49\end{array}$ & $\begin{array}{c}\text { Ст. 11- } \\
13\end{array}$ & Ст. 10 \\
\hline $\begin{array}{l}\text { Земельний кодекс } \\
(2002)\end{array}$ & & ст.133 & ст.133 & & & & ст.201 & & \\
\hline $\begin{array}{l}\text { ЗУ «Про іпотечне } \\
\text { кредитування, опе- } \\
\text { рації з консолідова- } \\
\text { ним іпотечним бор- } \\
\text { гом та іпотечні сер- } \\
\text { тифікати» (2004) }\end{array}$ & ст. 5,7 & & $\begin{array}{c}\text { ст.34 } \\
40\end{array}$ & & + & & & Розділ 1 & \\
\hline $\begin{array}{l}\text { Господарський ко- } \\
\text { декс (2003) }\end{array}$ & $\begin{array}{l}\text { ст. } 144, \\
147\end{array}$ & & ст.334 & пар.3 & ст.163 & ст.16 & & & $\begin{array}{l}\text { ст.352- } \\
355\end{array}$ \\
\hline $\begin{array}{l}\text { Цивільний кодекс } \\
(2003)\end{array}$ & & ст. 575 & & & & & ст.582 & $\begin{array}{c}\text { ст. 577, } \\
1057\end{array}$ & ст.581 \\
\hline $\begin{array}{l}\text { ЗУ «Про цінні папе- } \\
\text { ри та фондовий ри- } \\
\text { нок» (2006) }\end{array}$ & & & & $\begin{array}{c}\text { ст. } 2 \text {, } \\
17\end{array}$ & ст. 3,15 & & & & \\
\hline $\begin{array}{l}\text { Проект Закону «Про } \\
\text { ринок земель» } \\
\text { № } 7112 \text { від } \\
14.09 .2017 .\end{array}$ & $\begin{array}{c}\text { ст.3, } \\
\text { розділ } 2\end{array}$ & ст.3,13 & & ст. 4 & & & ст.9 & & \\
\hline
\end{tabular}

В Законах України «Про державну реєстрацію речових прав на нерухоме майно та їх обмежень», «Про іпотеку», Земельному кодексі України [9] передбачені вимоги щодо здійснення обов'язкової суцільної реєстрації прав на нерухоме майно, а також їх обмежень та обтяжень, відповідно до яких заявник (фізична або юридична особа - власник майна, інший правонабувач, сторона правочину, у яких виникло речове право або уповноважені ними особи тощо) у разі зміни прав власності або інших прав зобов'язаний звернутись до державного реєстратора з метою здійснення перереєстрації. 
Варто звернути увагу, що відповідно до законодавства відомості Державного реєстру речових прав на нерухоме майно є публічними та доступними. 3 огляду на сучасні світові тенденції розвитку іпотечного кредитування та прагнення розвинутих держав спростити та максимально стандартизувати процедуру фінансування діяльності суб'єктів господарювання під заставу нерухомості, законодавчо передбачена наявність доступу до баз даних щодо обтяжень та обмежень майна та майнових прав, що $є$ одним з основних компонентів продуктивного розвитку системи іпотечного кредитування аграрної сфери України.

Відповідно до ст. 28, 31 та 32 Закону України «Про іпотеку»та ст. 34 і 40 Закону України «Про іпотечне кредитування, операції 3 консолідованим іпотечним боргом та іпотечні сертифікати» основним іпотечним кредитодавцем в Україні $є$ банк-керуючий іпотекою, що відповідає наступній вимозі: загальний обсяг заборгованості за договорами про іпотечний кредит, наданими цим банком у національній валюті, які можуть бути реформовані у консолідований іпотечний борг, становить суму, еквівалентну не менше ніж 5 мільйонам євро за курсом Національного банку України. Банк-керуючий іпотекою на ринку рефінансування може також виступати в якості емітента іпотечних сертифікатів - іпотечних цінних паперів, забезпечених іпотечними активами або іпотеками. Емітентом таких сертифікатів можуть бути і небанківські фінансові установи, що відповідають вимогам Закону.

Відповідно до іпотечного законодавства іпотечний договір укладається між одним або декількома іпотекодавцями та іпотекодержателем у письмовій формі і підлягає обов'язковому нотаріальному посвідченню.

Вітчизняне іпотечне правове поле передбачає існування наступних видів іпотечних цінних паперів:

- заставна - іпотечний цінний папір, який засвідчує безумовне право його власника на отримання від боржника виконання за основним зобов'язанням, за умови, що воно підлягає виконанню в грошовій формі, а в разі невиконання основного зобов'язання - право звернути стягнення на предмет іпотеки;

- іпотечна облігація - іменний цінний папір, який засвідчує внесення грошових коштів її власником і підтверджує зобов'язання емітента відшкодувати йому номінальну вартість цієї облігації та грошового доходу в порядку, встановленому Законом України «Про іпотечні облігації» та проспектом емісії, а в разі невиконання емітентом зобов'язань за іпотечною облігацією надає її власнику право задовольнити свою вимогу за рахунок іпотечного покриття; 
- іпотечний сертифікат - іпотечний цінний папір, забезпечений іпотечними активами або іпотеками. Іпотечні сертифікати бувають двох видів - сертифікат участі та сертифікат з фіксованою дохідністю.

Іпотекодержатель, з метою рефінансування наданих кредитів, згідно з Законом України «Про іпотеку» має право здійснювати фінансові операції за наступним напрямками:

- продаж заставної шляхом здійснення передавального напису (індосаменту) з подальшою виплатою іпотекодержателю вартості заставної;

- передача заставної у заставу з метою погашення власних боргових зобов'язань іпотекодержателя;

- продаж заставної із зобов'язанням зворотного викупу (операція репо);

- випуск іпотечних цінних паперів, забезпечених заставними.

Кредитор відповідно до розділу II Закону України «Про іпотечне кредитування, операції з консолідованим іпотечним боргом та іпотечні сертифікати» має право здійснювати реформування іпотечних активів, якими він володіє, з метою оптимізації фінансових потоків. Таким чином, кредитодавець за потреби реформує іпотечні зобов'язання певної кількості боржників у консолідований іпотечний борг, при цьому одночасно формуючи іпотечний пул, який є об'єднанням іпотек за іпотечними договорами, що забезпечує виконання основних зобов'язань, реформованих у консолідований іпотечний борг. Трансформація іпотечних зобов'язань в іпотечні активи здійснюється фінансовою установою з метою реалізації операцій з відчуження іпотечних активів.

Стосовно функціонування земельно-іпотечного кредитування господарської діяльності суб'єктів підприємництва можна стверджувати про наявність значних обмежень щодо використання земельних ділянок в якості застави. 3 одного боку, право застави земельних ділянок, зокрема земель сільськогосподарського призначення, передбачене ст. 133 Земельного кодексу України та ст. 15 Закону України «Про іпотеку». Водночас, ст. 4 Закону України «Про заставу» стверджує, що предметом застави може бути майно, яке відповідно до законодавства України може бути відчужено заставодавцем та на яке може бути звернено стягнення. Саме процедура відчуження земельних ділянок сільськогосподарського призначення пов'язана 3 рядом перепон та проблемних моментів, що певним чином гальмують розвиток земельно-іпотечного кредитування.

Відповідно до ст. 14, 15 розділу $X$ «Перехідні положення» Земе- 
льного кодексу України «до набрання чинності законом про обіг земель сільськогосподарського призначення, але не раніше 1 січня 2019 року, забороняється внесення права на земельну частку (пай) до статутних капіталів господарських товариств, а також не допускається купівля-продаж земельних ділянок сільськогосподарського призначення державної та комунальної власності, крім вилучення (викупу) їх для суспільних потреб; купівля-продаж або іншим способом відчуження земельних ділянок і зміна цільового призначення (використання) земельних ділянок, які перебувають у власності громадян та юридичних осіб для ведення товарного сільськогосподарського виробництва, земельних ділянок, виділених в натурі (на місцевості) власникам земельних часток (паїв) для ведення особистого селянського господарства, а також земельних часток (паїв), крім передачі їх у спадщину» [9]. Таке положення речей збільшує ризики ринкової ліквідності кредитора при земельно-іпотечному кредитуванні агропідприємств, фермерських та особистих селянських господарств, а також знижує заставний потенціал у суб'єктів аграрного бізнесу, тим самим знижуючи їх доступ до можливості покращувати якості земель та кормів, створювати нові робочі місця, виходити з готовою продукцією належної якості на зовнішні ринки.

Таким чином, законодавче забезпечення розвитку аграрної сфери України, зокрема через процедуру надання іпотечних кредитів для фінансування будівництва та купівлю сільськогосподарської техніки та інших засобів виробництва, в цілому знаходиться на належному рівні, включає в себе комплекс законів та підзаконних нормативно-правових актів, що регулюють відносини в даній галузі. Трансформаційні процеси в економіці держави після отримання незалежності і до сьогодення вимагають постійного оновлення і актуалізації діючих норм законодавства. Зважаючи на це, можна сказати, що більшість невідповідностей у чинному законодавчому доробку зумовлено саме наявністю перехідних періодів та розбіжностей поглядів учасників законотворчого процесу на різних етапах становлення незалежної економіко-політичної системи. Проведений нами аналіз діючого законодавства України у сфері іпотечного кредитування агропромислового комплексу та зареєстрованих на даний час законопроектів [10] щодо запровадження ринку земель дає змогу стверджувати про те, що існуючий порядок інвестування в аграрну сферу $\epsilon$ недосконалим і потребує подальшої оптимізації з метою покращення умов доступу до позикових фінансових ресурсів суб'єктів малого та середнього агробізнесу. 
1. Мохова Ю. Л. Сутність та складові механізму державного регулювання іпотечного кредитування в Україні. Держава та регіони. Сер. Державне управління. 2012. № 2. С. 88-90. 2. Про іпотеку : Закон України від 05.06.2003 № 898-IV, редакція від 06.11.2014. URL: http://zakon0.rada.gov.ua/laws/show/898-15. (дата звернення: 15.03.2019). 3. Мельник Л. В. Державне регулювання та підтримка використання ресурсного потенціалу іпотечного кредитування в аграрній сфері. Економіка і суспільство. 2017. Випуск 13. С. 1165-1172. 4. Про іпотечне кредитування, операції з консолідованим іпотечним боргом та іпотечні сертифікати : Закон України від 19.06.2003 № 979-IV, редакція від 06.12.2012. URL: http://zakon3.rada.gov.ua/laws/show/979-15. (дата звернення: 15.03.2019). 5. Про іпотечні облігації : Закон України від 22.12.2005 № 3273-IV, редакція від 18.08.2012. URL: http://zakon5.rada.gov.ua/laws/show/3273-15. (дата звернення: 15.03.2019). 6. Про оцінку земель: Закон України від 11.12.2003 № 1378- IV, редакція від 02.03.2015 URL: http://zakon5.rada.gov.ua/laws/show/1378-15/print1453789251116969. (дата звернення: 15.03.2019). 7. Про державну реєстрацію речових прав на нерухоме майно : Закон України від 01.07.2004 № 1952-IV, редакція від 01.01.2016. URL: http://zakon3.rada.gov.ua/laws/show/1952-15. (дата звернення: 15.03.2019)._8. Про заставу: Закон України від 02.10.1992 № 2654XII, редакція від 22.08.2018. URL: http://zakon.rada.gov.ua/laws/show/265412. (дата звернення: 15.03.2019). 9. Земельний кодекс України, редакція від 12.10.2018. URL: http://zakon.rada.gov.ua/laws/show/2768-14. (дата звернення: 15.03.2019). 10. Про ринок земель: проект Закону від 14.09.2017 р. № 7112

URL: http://w1.c1.rada.gov.ua/pls/zweb2/webproc4_1?pf3511=62540 (дата звернення: 15.03.2019).

\section{REFERENCES:}

1. Mokhova Yu. L. Sutnist ta skladovi mekhanizmu derzhavnoho rehuliuvannia ipotechnoho kredytuvannia v Ukraini. Derzhava ta rehiony. Ser. Derzhavne upravlinnia. 2012. № 2. S. 88-90. 2. Pro ipoteku : Zakon Ukrainy vid 05.06.2003 № 898-IV, redaktsiia vid 06.11.2014. URL: http://zakon0.rada.gov.ua/laws/show/898-15. (data zvernennia: 15.03.2019). 3. Melnyk L. V. Derzhavne rehuliuvannia ta pidtrymka vykorystannia resursnoho potentsialu ipotechnoho kredytuvannia $v$ ahrarnii sferi. Ekonomika $i$ suspilstvo. 2017. Vypusk 13. S. 1165-1172. 4. Pro ipotechne kredytuvannia, operatsii z konsolidovanym ipotechnym borhom ta ipotechni sertyfikaty : Zakon Ukrainy vid 19.06.2003 № 979-IV, redaktsiia vid 06.12.2012. URL: http://zakon3.rada.gov.ua/laws/show/979-15. (data zvernennia: 15.03.2019). 5. Pro ipotechni oblihatsii : Zakon Ukrainy vid 22.12.2005 № 3273-IV, redaktsiia vid 18.08.2012. URL: http://zakon5.rada.gov.ua/laws/show/3273-15. (data zvernennia: 15.03.2019). 6. Pro otsinku zemel: Zakon Ukrainy vid 11.12.2003 № 1378- IV, redaktsiia vid 02.03.2015 URL: 
http://zakon5.rada.gov.ua/laws/show/1378-15/print1453789251116969.

(data zvernennia: 15.03.2019). 7. Pro derzhavnu reiestratsiiu rechovykh prav na nerukhome maino : Zakon Ukrainy vid 01.07.2004 № 1952-IV, redaktsiia vid 01.01.2016. URL: http://zakon3.rada.gov.ua/laws/show/1952-15. (data zvernennia: 15.03.2019). 8. Pro zastavu: Zakon Ukrainy vid 02.10.1992 № 2654Khll, redaktsiia vid 22.08.2018. URL: http://zakon.rada.gov.ua/laws/show/2654-12. (data zvernennia: 15.03.2019). 9. Zemelnyi kodeks Ukrainy, redaktsiia vid 12.10.2018. URL: http://zakon.rada.gov.ua/laws/show/2768-14. (data zvernennia: 15.03.2019). 10. Pro rynok zemel: proekt Zakonu vid 14.09.2017 r. № 7112 URL: http://w1.c1.rada.gov.ua/pls/zweb2/webproc4_1?pf3511=62540 (data zvernennia: 15.03.2019).

Melnyk L. V., Candidate of Economics (Ph.D.), Associate

Professor (National University of Water and Environmental Engineering, Rivne)

\section{ANALYSIS OF LEGISLATIVE BASIS ON MORTGAGE LENDING OF AGRICULTURAL PRODUCERS}

Providing favorable conditions for the existence of the agrarian business is impossible without the participation of the state as a subject of regulation and participant in economic relations. The purpose of the article is to investigate the existing legislative framework on state regulation and support for mortgage lending and to identify areas for its improvement.

The article classifies the legislative acts that determine the legal basis for the functioning of mortgage lending in Ukraine, in particular: the issue of regulation of the use of property rights to real estate, land mortgages, mortgage institutions, infrastructure institutions, mortgage securities, state agricultural support programs, farmers, mortgage documentation, mortgage real estate insurance.

The analysis of the domestic legal framework regarding lending on secured real estate, including agricultural land, makes it possible to conclude that there is a sufficiently clear procedure for lending to individuals and legal entities secured by real estate and property rights.

Legislative support for the development of the agricultural sector of Ukraine, in particular through the procedure of granting mortgages to finance the construction and the purchase of agricultural machinery and other means of production, includes a set of laws and regulations that regulate relations in this field. 
With regard to the functioning of land-based mortgage lending to businesses of business entities, it can be argued that there are significant restrictions on the use of land plots as collateral. Most of the inconsistencies in the current legislative developments are due to the existence of transitional periods and divergences of views of the participants of the legislative process at different stages of the formation of an independent economic and political system. The current order of investing in the agricultural sector needs further optimization in order to improve the conditions for access to small and medium-sized agribusiness entities.

Keywords: state regulation of mortgage lending, mechanism of state regulation, land-mortgage lending, agrarian production.

Мельник Л. В., к.э.н., доцент (Национальный университет водного хозяйства и природопользования, г. Ровно)

\section{АНАЛИЗ ЗАКОНОДАТЕЛЬНОЙ БАЗЫ ИПОТЕЧНОГО КРЕДИТОВАНИЯ СЕЛЬСКОХОЗЯЙСТВЕННЫХ ПРОИЗВОДИТЕЛЕЙ}

В статье проведен анализ действующей законодательной базы по вопросам ипотечного кредитования сельскохозяйственных производителей. Представлена сравнительная характеристика законодательных актов, определяющих правовые основы функционирования ипотечного кредитования. Систематизированы виды ипотечных ценных бумаг. Обоснована потребность в дальнейшей оптимизации нормативно-правовой базы с целью улучшения условий доступа к ресурсам субъектов малого и среднего агробизнеса.

Ключевые слова: государственное регулирование ипотечного кредитования, механизм государственного регулирования, земельноипотечное кредитование, аграрное производство. 